Psikologia (Jurnal Psikologi), Vol 2 (2), July 2017, 65-80

ISSN 2338-8595 (print), ISSN 2541-2299 (online)

Journal Homepage:

http://ojs.umsida.ac.id/index.php/psikologia

DOI Link: 10.21070/psikologia.v2i2.975

\title{
PENGHAYATAN HIDUP BAHAGIA DAN KESEJAHTERAAN PADA KAUM PEMULUNG
}

\author{
Bonar Hutapea $^{1}(\mathrm{D})$, Tasya Qurrata A'yun ${ }^{2}, \mathrm{Cherika}^{3}$, Regina Natashya ${ }^{4}$, Ricka Noviana ${ }^{5}$, \\ Susanthy Margareth ${ }^{6}$ \\ 1, 2,3,4,5,6 Fakultas Psikologi, Universitas Tarumanagara, Jakarta Barat, Indonesia
}

\begin{abstract}
The Social Welfare Issuer (PMKS) is a person or family who, because of an obstacle, difficulty or disruption, can not carry out their social functions and therefore can not establish a harmonious and creative relationship with their environment so that they can not fulfill their (physical, spiritual and social) needs adequate and reasonable (Thamrin, Masril \& Sembiring, 2016). This research has a point to find out how an illustration the depth to live happily and prosperous people the scavengers. A method is executed by qualitative narrative, by interview depth and observation. Researchers had conducted interviews with two subjects that work as scavengers. Results in getting is the depth to live happily of both the subject of very simple with the fulfill of needs and there is also social security for them. They could only fulfill their needs by gathering used goods erratic the amounts of each day and it becomes happiness its own for both subject. However in fact what happens is that social services agency and the central administration has not given a guarantee or assistance which could be used by both subject. Researchers advice for governments is to give the assurance that it is set in accordance with law social welfare, so that the scavengers can receive their rights.
\end{abstract}

Keyword: Well being, Cities, Homelessness, The social welfare issuer (PMKS)

\begin{abstract}
ABSTRAK
Penyandang Masalah Kesejahteraan Sosial (PMKS) adalah seseorang atau keluarga yang karena suatu hambatan, kesulitan atau gangguan tidak dapat melaksanakan fungsi sosialnya dan karenanya tidak dapat menjalin hubungan yang serasi dan kreatif dengan lingkungannya sehingga tidak dapat memenuhi kebutuhan hidupnya (jasmani, rohani dan sosial) secara memadai dan wajar. Penelitian ini memiliki tujuan untuk mengetahui bagaimana gambaran penghayatan hidup bahagia dan sejahtera pada kaum pemulung. Metode yang dilakukan adalah kualitatif naratif, dengan melakukan wawancara secara mendalam dan observasi. Peneliti telah melakukan wawancara dengan 2 subyek yang berprofesi sebagai pemulung. hasil yang di dapatkan adalah penghayatan dari hidup bahagia dari kedua subyek sangat sederhana dengan terpenuhinya kebutuhan-kebutuhan mereka dan juga ada jaminan sosial bagi mereka. Mereka hanya dapat memenuhi kebutuhannya dengan mengumpulkan barang-barang bekas yang tidak menentu jumlah setiap harinya dan itu menjadi kebahagiaan tersendiri bagi kedua subyek. Akan tetapi kenyataannya yang terjadi adalah Dinas Sosial dan Pemerintahan Pusat tidak memberikan jaminan atau bantuan yang dapat mempermudah para subyek. Saran peneliti bagi pemerintahan adalah memberikan jaminan yang sudah diatur sesuai dengan UU Kesejahteraan Sosial, sehingga para pemulung dapat menerima haknya.
\end{abstract}

Keyword: Kesejahteraan, Perkotaan, Pengangguran, Penyandang Masalah Kesejahteraan Sosial $(P M K S)$ 


\section{PENDAHULUAN}

Indonesia merupakan suatu negara yang kaya akan sumber daya, baik alam (SDA) maupun manusia (SDM). Saat ini, keberhasilan suatu negara dapat dilihat dari keberhasilannya dalam meningkatkan kesejahteraan sosial masyarakat negara tersebut. Penyandang Masalah Kesejahteraan Sosial (PMKS) adalah seseorang atau keluarga yang karena suatu hambatan, kesulitan atau gangguan tidak dapat melaksanakan fungsi sosialnya dan karenanya tidak dapat menjalin hubungan yang serasi dan kreatif dengan lingkungannya sehingga tidak dapat memenuhi kebutuhan hidupnya (jasmani, rohani dan sosial) secara memadai dan wajar (Thamrin, Masril, \& Sembiring, 2016).

Kesejahteraan sosial adalah kondisi terpenuhinya kebutuhan material, spiritual, dan sosial warga negara agar dapat hidup layak dan mampu mengembangkan diri sehingga dapat melaksanakan fungsi sosialnya (UU No. 11 pasal 1, 2009). Dalam Undang-Undang No 11 tahun 2009 pasal 2, kesejahteraan sosial merupakan suatu keadaan terpenuhinya kebutuhan hidup yang layak bagi masyarakat, sehingga mampu mengembangkan diri dan dapat melaksanakan fungsi sosialnya yang dapat dilakukan pemerintah, pemerintah daerah dan masyarakat dalam bentuk pelayanan sosial yang meliputi rehabilitasi sosial, jaminan sosial, pemberdayaan sosial, dan perlindungan sosial (Dinsos Jakarta, 2017).

Namun, kesejahteraan sosial berhubungan dekat dengan masalah sosial. Ketika kesejahteraan sosial suatu negara tercapai atau terpenuhi maka tingkat masalah sosialnya juga rendah. Sebaliknya, ketika kesejahteraan sosial negara tersebut tidak terpenuhi maka tingkat masalah sosialnya tinggi. Individu yang mengalami masalah sosial dapat disebut sebagai penyandang masalah kesejahteraan sosial (PMKS).

Penyandang Masalah Kesejahteraan Sosial (PMKS) adalah seseorang, keluarga, atau kelompok masyarakat yang karena suatu hambatan, kesulitan, atau gangguan tidak dapat melaksanakan fungsi sosialnya sehingga tidak terpenuhi kebutuhan hidupnya baik jasmani, rohani, maupun sosial secara memadai dan wajar (Thamrin, Masril, \& Sembiring, 2016). Hambatan, kesulitan, atau gangguan tersebut dapat berupa kemiskinan, ketelantaran, kecacatan, ketunaan sosial, keterbelakangan, keterasingan/ketertinggalan, dan bencana 
alam maupun bencana sosial (Kemsos, 2008).

Menurut Kementerian Sosial RI (Dinsos Jakarta, 2017), terdapat 26 jenis PMKS di Jakarta dengan beberapa batasan yang telah ditetapkan oleh Dinas Sosial. Indonesia merupakan salah satu negara berkembang yang tak luput dari adanya PMKS, jumlah PMKS di Indonesia khususnya di provinsi DKI Jakarta pada Mei 2017 adalah 18.387 jiwa (Dinsos Jakarta, 2017). Jumlah PMKS bertambah dari tahun 2016 yaitu 14.109 jiwa. Data tersebut termasuk Kepulauan Seribu, Jakarta Barat, Jakarta Timur, Jakarta Utara, Jakarta Selatan, dan Jakarta Pusat.

Salah satu kaum PMKS yang sering ditemui dimana saja adalah pemulung. Pemulung adalah orang-orang yang memiliki pekerjaan dengan mengumpulkan barang-barang bekas yang masih dapat terpakai dengan cara didaur ulang. Seseorang dikatakan merupakan pemulung apabila masuk dalam kriteria tidak mempunyai pekerjaan tetap atau mengais langsung dan mendaur ulang barang bekas, dll.

\section{Well- being}

Hambatan, kesulitan, atau gangguan tersebut kemungkinan akan berpengaruh terhadap psychological well-being para
PMKS. Menurut Kartikasari (2013) kesejahteraan psikologis (psychological well-being) merupakan suatu kondisi tertinggi yang dapat dicapai oleh individu yang mencakup evaluasi dan penerimaan diri pada berbagai aspek kehidupan tidak hanya berupa aspek positif namun juga aspek negatif yang terbagi dalam enam dimensi, yaitu: dimensi penerimaan diri, dimensi hubungan positif dengan orang lain, dimensi otonomi, dimensi penguasaan lingkungan, tujuan hidup dan dimensi pengembangan pribadi.

Individu dengan psychological wellbeing yang baik akan memiliki kemampuan untuk memilih dan menciptakan lingkungan sesuai dengan kondisi fisik dirinya. Dengan kata lain mempunyai kemampuan dalam menghadapi kejadian-kejadian di luar dirinya (Alvian, 2010). Selain itu individu juga dapat menerima kekuatan dan kelemahan diri sendiri sebagaimana adanya, memiliki hubungan positif dengan orang lain, mampu mengarahkan perilakunya sendiri (Alvian, 2010).

Menurut Ryff (1989), psychological well-being merupakan realisasi dan pencapaian penuh dari potensi individu dimana individu dapat menerima kekurangan dan kelebihan dirinya, 
mandiri, mampu membina hubungan positif dengan orang lain, dapat menguasai lingkungannya dalam arti memodifikasi lingkungannya agar sesuai dengan keinginannya, memiliki tujuan hidup, serta terus mengembangkan pribadinya.

Psychological well-being dapat diartikan sebagai suatu kebahagiaan (Bradburn dalam Ryff, 1989). Ketika individu atau kelompok PMKS mencapai tingkat psychological well-beingnya, maka akan menghasilkan suatu perasaan bahagia. Artinya, kebahagiaan merupakan suatu hasil dari pencapaian psychological well-being tersebut.

Dari beberapa definisi tersebut dapat disimpulkan bahwa kesejahteraan psikologis merupakan suatu kondisi tertinggi yang dapat dicapai oleh individu yang mencakup evaluasi dan penerimaan diri pada berbagai aspek kehidupan serta merasa puas dalam kehidupan (Ryff, 1989).

Menurut Ryff (dalam Ryff, \& Singer, 2008) aspek-aspek yang menyusun psychological well-being antara lain sebagai berikut.

Self Acceptance. Self acceptance atau penerimaan diri adalah individu yang memiliki nilai penerimaan diri yang tinggi, memiliki sikap positif pada dirinya mengakui dan menerima berbagai aspekyang ada dalam dirinya, baik yang bersifat baik maupun buruk serta merasa positif dengan kehidupan masa lalunya (Ryff, 1989).

\section{Positive Relations with Others.} Individu yang memiliki nilai tinggi pada dimensi ini makan akan mempunyai hubungan yang hangat, memuaskan dan saling percaya dengan orang lain, memperhatikan kesejahteraan orang lain, serta mempu memberikan empati yang kuat, afeksi dan hubungan yang timbal balik (Ryff, 1989).

Autonomy. Otonomi atau autonomy yang merupakan kemampuan untuk mengarahkan diri sendiri, kemandirian dan kemampuan untuk mengatur tingkah laku. Individu yang memiliki nilai tinggi pada dimensi ini maka akan mampu menghadapitekanan sosial, mengatur tingkah laku dan mengevaluasi diri dengan standar pribadi, serta mampu mengarahkan diri dan mandiri (Ryff, 1989).

Environmental mastery. Penguasaan lingkungan merupakan kemampuan untuk memilih dan menciptakan lingkungan yang sesuai dengan kondisi fisik dirinya. Individu yang memiliki nilai tinggi dalam dimensi ini akan mempunyai kuasa dan mengatur lingkungannya, mengontrol 
berbagai kegiatan eksternal yang kompleks, menggunakan kesempatankesempatan yang ada secara efektif, serta mampu memilih atau menciptakan konteks yang sesuai dengan kebutuhan-kebutuhan dan nilai-nilai pribadi (Ryff, 1989).

Purpose in life. Purpose in life merupakan kemampuan individu untuk menentukan tujuan dan arah dalam hidup.Individu yang memiliki nilai tinggi pada dimensi ini maka individu mempunyai tujuan dan arah hidup, serta merasakan arti dalam hidup masa kini dan lampau (Ryff, 1989).

Personal growth. Personal growth merupakan kemampuan individu untuk mengembangkan potensi dalam diri dan berkembang sebagai seorang manusia secara berkelanjutan. Individu yang memiliki nilai tinggi pada dimensi ini maka akan merasa ada perkembangan potensi diri yang berkelanjutan, menyadari potensi diri dan melihat ke-majuan dari waktu ke waktu, serta terbuka pada pengalaman baru (Ryff, 1989).

Berdasarkan penjelasan diatas dapat disimpulkan bahwa ada 6 (enam) aspekaspek yang dapat menyusun psychological well-being yaitu: penerimaan diri (self aceptance), hubungan positif dengan orang lain (positive relation with other), kemandirian (autonomy), penguasaan lingkungan, tujuan hidup (purpose in life) dan pengembangan pribadi (personal growth) (Ryff, 1989).

Berbagai penelitian mengenai psychological well-being telah banyak dilakukan dan dapat diketahui bahwa terdapat faktor-faktor yang mempengaruhi psychological well-being seseorang. Adapun faktor-faktor yang mempengaruhi psychological well-being antara lain ialah usia, adanya perbedaan usia diakui memberi pengaruh kepada psychological well-being. Hal ini didasarkan pada penelitian (Ryff, 1989 \& Snyder, 2002) yang menjelaskan bahwa terdapat perbedaan tingkat psychological wellbeing didasarkan dari perbedaan usia. Perbedaan usia ini terbagi dalam tiga fase kehidupan yaitu masa dewasa muda, dewasa tengah dan masa dewasa akhir.

Faktor berikutnya adalah jenis kelamin, perbedaaan jenis kelamin memberikan pengaruh tersendiri dari psychological well-being seseorang, dimana pada wanita cenderung memiliki kesejahteraan psikologis dibandingkan laki-laki. Hal ini terkait dengan pola pikir yang berpengaruh terhadap strategi coping dan aktifitas sosial yang dilakukan, dimana wanita lebih cenderung memiliki 
kemampuan interpersonal yang lebih baik dari pada laki-laki (Ryff \& Singer, 2008).

Dalam penelitian yang sama pula Ryff dan koleganya (dalam, Ryff Snyder, 2002) menjelaskan bahwa faktor status sosial ekonomi yang meliputi: tingkat pendidikan, tingkat pendapatan dan keberhasilan pekerjaan yang memberikan pengaruh tersendiri pada psychological well-being, dimana individu dengan tingkat pendidikan yang lebih tinggi dan memiliki pekerjaan yang baik akan menunjukan tingkat psychological wellbeing yang lebih tinggi pula. Ryff $\mathrm{dkk}$ (dalam, Ryan \& Deci, 2001) juga menjelaskan bahwa status sosial ekonomi berhubungan dengan dimensi dari penerimaan diri, tujuan dalam hidup, penguasaan lingkungan, dan pertumbuhan pribadi. Dan beberapa penelitian mendukung pendapat ini (Ryan \& Deci,2001) dimana individu-individu yang memfokuskan pada kebutuhan materi dan financial sebagai tujuannya menunjukan tingkat kesejahteraan yang rendah.

\section{Selain itu terdapat faktor dukungan} sosial dimana menurut Davis (dalam, Kartikasari 2013), individu-individu yang mendapatkan dukungan sosial memiliki tingkat psychological well-being yang lebih tinggi. Kemudian terdapat faktor religiusitas yang penelitiannya dilakukan oleh Koening, Smilery dan Gonzales (Santrock, 2002) menyatakan bahwa lansia yang lebih dekat dengan agama menunjukan tingkatan yang lebih tinggi dalam hal kepuasan hidup, harga diri dan optimisme. Hal ini mengungkapkan bahwa individu dengan tingkat religious yang sangat baik menunjukan tingkat psychological well-being yang lebih tinggi dan lebih sedikit mengalami pengalaman traumatik.

Faktor terakhir ialah kepribadian yang mana Schumutte dan Ryff melakukan penelitian mengenai hubungan antara lima tipe kepribadian dengan dimensi-dimensi psychological well-being, hasil dari penelitian Schummute dan Ryff menunjukkan bahwa individu yang termasuk dalam kategori kepribadian ekstraversion, conscientiousness, dan low neuroticism mempunyai dimensi pertumbuhan pribadi yang baik, individu dengan kepribadian agreeabless dan ekstraversion memiliki dimensi hubungan positif dengan orang lain yang baik dan individu yang termasuk kategori low neuroticism mempunyai skor tinggi pada dimensi otonomi (Ryan \& Deci, 2001; Kartikasari, 2013). 


\section{Kebahagiaan}

Menurut Aristoteles (dalam Williams dkk, 2006), kebahagiaan merupakan bentuk kesempurnaan, sehingga banyak upaya yang dilakukan untuk mencapainya. Hal ini senada dengan apa yang disampaikan oleh James bahwa kebahagiaan merupakan hal yang sangat penting sehingga upaya untuk mencapai kebahagiaan menjadi fokus perhatian dan tujuan dari manusia sepanjang waktu. Dengan demikian jelas bahwa setiap orang tampaknya ingin mencapai kebahagiaan dan akan berusaha melakukan upaya tertentu untuk mencapai kebahagiaan dalam hidupnya.

Sementara menurut Diener \& Ryan (2009), kebahagiaan mengacu kepada emosi yang bersifat positif, sedangkan subjective well-being mencakup emosi yang positif maupun negatif. Namun demikian kedua istilah tersebut menunjukkan penilaian individu terhadap kualitas hidupnya. Dari berbagai teori tentang kebahagiaan di atas, dapat disimpulkan bahwa kebahagiaan merupakan penilaian seseorang akan kualitas hidupnya yang ditandai dengan adanya emosi yang menyenangkan dan rasa puas dengan kehidupannya.
Banyak perdebatan yang muncul mempertanyakan apakah kebahagiaan itu merupakan suatu keadaan yang bersifat sementara dan dipengaruhi oleh situasi yang terjadi (state) atau merupakan bagian dari kepribadian seseorang yang bersifat tetap (trait)? Pertanyaan ini muncul mengingat terkadang orang akan merasa bahagia dalam hidupnya, namun kadang ia merasa tidak bahagia dengan apa yang terjadi dalam hidupnya. Menurut Veenhoven (dalam Patnani, 2012), penelitian yang bersifat longitudinal menunjukkan bahwa kebahagiaan ternyata stabil dalam jangka pendek, namun tidak dalam jangka waktu panjang. Hal ini tentunya membuktikan bahwa kebahagiaan bukan merupakan trait, karena sifat dari trait adalah relatif stabil dan konsisten dalam jangka panjang. Dari teori ini dapat disimpulkan bahwa rasa bahagia sangat dipengaruhi oleh situasi yang dihadapi. Jika menghadapi situasi yang menyenangkan, orang merasa bahagia, namun jika suatu saat menghadapi situasi yang tidak menyenangkan maka kebahagiaan itu akan digantikan oleh emosi yang negatif.

Namun demikian ada beberapa ahli yang berpendapat lain dan berkeyakinan bahwa kebahagiaan merupakan suatu trait. 
Penelitian yang dilakukan oleh Magnus dan Diener (dalam Diener dkk, 1999) menunjukkan bahwa kepuasan hidup seseorang mampu bertahan sampai 4 tahun. Selain itu, penelitian yang dilakukan oleh Heady dan Wearing (dalam Diener dkk, 1999) menunjukkan bahwa setiap orang memiliki dasar emosi positif dan negatif yang relatif stabil, sehingga ketika seorang individu mengalami peristiwa yang menyenangkan atau tidak menyenangkan, ia akan kembali pada dasar emosinya tersebut.

Dari teori ini dapat disimpulkan bahwa situasi eksternal memang akan mempengaruhi emosi seorang individu, namun biasanya pengaruh tersebut tidak akan besar karena individu tersebut akan cenderung kembali kepada dasar emosi yang dimilikinya. Dengan demikian, orang yang pada dasarnya memiliki rasa bahagia, maka ketika menghadapi situasi yang tidak menyenangkan, responnya terhadap kejadian tersebut akan bersifat sementara dan ia akan kembali pada rasa bahagia.

Ada banyak hal yang dapat membuat seseorang merasa bahagia. Hal-hal yang mempengaruhi kebahagiaan mungkin berbeda pada setiap orang. Satu hal yang dianggap sebagai sumber kebahagiaan bagi seorang individu, belum tentu menjadi sumber kebahagiaan bagi individu lain. Menurut Diener dan Ryan (2009), beberapa faktor yang mempengaruhi kebahagiaan seseorang adalah: kecerdasan emosional, religiusitas, relasi sosial, pekerjaan dan tingkat pendapatan. Dengan demikian, dapat dikatakan bahwa individu akan merasa bahagia jika memiliki kecerdasan emosi yang baik, bersikap religius, memiliki hubungan sosial yang baik, dan memiliki pekerjaan dan penghasilan yang memuaskan. Sebaliknya jika hal-hal tersebut tidak dimiliki oleh seorang individu, maka individu tersebut tidak merasakan kebahagiaan dalam hidupnya.

\section{METODE PENELITIAN}

Penelitian ini merupakan penelitian kualitatif dengan desain penelitian naratif. Desain penelitian kualitatif naratif menurut John W. Creswell (2004) adalah studi pendekatan yang berfokus pada narasi, cerita, atau deskripsi tentang serangkaian peristiwa terkait dengan pengalaman manusia. Pada pendekatan naratif ini, prosedur yang digunakan adalah restoring, yakni penceritaan kembali cerita tentang pengalaman individu mengenai kehidupannya sehari-hari yang sesuai dengan topik penelitian. Pengumpulan 
datanya dilakukan dengan wawancara mendalam dan observasi subyek. Analisisnya berpijak pada kronologi peristiwa yang menekankan pada titik-balik atau ephiphanies dalam kehidupan partisipan.

Pada penelitian ini, dilakukan 2 kali di daerah Grogol pada tanggal 4 April 2017 pada pukul 10.00 dan dilanjutkan pada tanggal 2 Mei 2017 pada pukul 09.30. Peralatan yang digunakan yaitu pedoman wawancara, informed consent, alat perekam, kertas dan pensil. Dalam penelitian ini tidak ada batasan gender, suku/ras, maupun usia pada kedua subyek. Kriteria subyek dalam penelitian ini adalah seseorang yang berprofesi sebagai pemulung di kota Jakarta. Kemudian peneliti pun memulai sesi wawancara dengan mengacu pada pedoman wawancara yang telah disediakan oleh peneliti. Subyek pertama tidak dapat menulis data dirinya dan tanda tangannya pada lembar Informed Consent, maka dengan izin subyek, data diri subyek diisi oleh peneliti dan peneliti yang menandatangani data pada Informed Consent tersebut. Wawancara tersebut berlangsung selama kurang lebih 15-20 menit.
Peneliti telah melakukan wawancara dan observasi kepada 2 subyek yang mengalami kondisi yang berbeda. Subyek 1 merupakan seorang kakek berusia 74 tahun dan hidup seorang diri di kolong jembatan daerah Jakarta, sedangkan subyek 2 merupakan seorang ibu tunggal yang memiliki seorang anak laki-laki dan tinggal di pemukiman kumuh di Jakarta. Kedua subyek berprofesi sebagai pemulung, dan biasa mengumpulkan barang-barang bekas di daerah Grogol, Jakarta Barat. Setelah peneliti mendapatkan informasi dari kedua subyek, peneliti pun mengolah data-data dari kedua subyek dan menganalisis data-data tersebut dengan mengkaitkan dari teori yang ada dan dari jurnal yang disediakan dengan membahas penghayatan hidup bahagia dan kesejahteraan pada kaum pemulung.

\section{HASIL PENELITIAN}

\section{Subyek 1}

Subyek merupakan seorang kakek yang lahir pada tahung 1942, berumur 74 tahun, dan berprofesi sebagai pemulung. Subyek memiliki keluarga yang tinggal di kampung halamannya. Keluarga subyek dikaruniai oleh beberapa anak. Subyek mengalami stroke ringan di sebagian 
tubuhnya. Sehari-hari, subyek memulung barang-barang bekas seperti botol-botol plastik dan kardus di sekitar daerah Grogol dengan cara menyeret bagian kaki yang mengalami stroke. Untuk mengangkat tongkat pengait, beliau merasakan sakit. Keluarga subyek mengetahui penyakit yang dialaminya namun tidak mengetahui kegiatan yang dilakukan oleh subyek di kota Jakarta. Subyek telah memulung selama hampir 5 tahun. Untuk setiap $1 \mathrm{~kg}$ dari hasil barang bekas yang dipungut oleh subyek berkisar Rp 4,000. Penghasilan subyek R dalam sehari sekitar Rp 4,000 Rp 8,000. Untuk bermalam, subyek $\mathrm{R}$ dapat tidur dimana saja, tetapi lebih sering di kolong jembatan daerah Jakarta Barat.

Mengenai layanan Dinas Sosial yang ada di daerah kota Jakarta, subyek R menolaknya. Hal ini dikarenakan untuk mendapatkan pelayanan dari Dinas Sosial memerlukan banyak persiapan. Apabila ditawarkan untuk masuk ke panti sosial, subyek bertanggapan bahwa apabila beliau berada di panti tersebut dan mengalami sakit seperti saat ini, layanan panti sosial tersebut cenderung tidak mengobati sakitnya. Subyek tidak mendapatkan perawatan ataupun rehabilitasi mengenai strokenya. Namun, menurut subyek tak jarang petugas keamanan dan ketertiban
(KAMTIB) memberikan tunjangantunjangan kepada para pemulung yang berada di kolong sekitar daerah Grogol.

Tidak ada harapan khusus dari subyek terhadap layanan Dinas Sosial yang ada di kota karena subyek beranggapan karena beliau sudah tua. Namun, untuk harapan pribadi dari subyek $\mathrm{R}$ untuk hidupnya yaitu agar beliau dapat membuka kedai-kedai kopi atau warung untuk berjualan.

\section{Subyek 2}

Subyek merupakan seorang ibu tunggal yang memiliki 1 orang anak lakilaki. Subyek tinggal di pemukiman kumuh di daerah Jakarta. Sehari-hari subyek mengumpulkan barang-barang bekas seperti botol plastik, kardus dan juga kayukayu bekas untuk kembali dijual di penampungan yang menerima rongsokan. Subyek berasal dari Banyumas, dan berada di Jakarta semenjak 8 tahun yang lalu. Ia datang ke Jakarta bersama saudaranya tetapi saat ini saudaranya hilang dan tidak ada kabar sama sekali. Suami subyek pun yang ia temui di Jakarta pergi meninggalkannya setelah terlilit banyak hutang, sehingga subyek membiayai anaknya seorang diri. Anaknya berusia 8 tahun dan saat ini sudah putus sekolah karena keterbatasan biaya. Subyek sehari 
mendapatan Rp 20,000 hingga Rp 30,000 sehari jika berhasil mengumpulkan banyak barang bekas.

Subyek merasa bahwa pemerintah pun kurang dalam menjamin kesejahteraan hidup dirinya. Subyek belum pernah ditampung oleh Dinas Sosial karena biasanya Dinas Sosial lebih mengutamakan orang-orang yang tinggal dipinggir jalan dan juga kolong jembatan. Setelah subyek mengetahui bahwa ada Undang-Undang mengenai Kesejahteraan Sosial, subyek berharap adanya jaminan sosial baginya dan anaknya sehingga Pemerintah dapat membiayai anaknya kembali sekolah.

Subyek tidak berharap banyak tentang kepedulian seseorang akan dirinya dan anaknya. yang terpenting anaknya tetap bersamanya dan dapat makanan yang cukup. Subyek merasa kurang mengerti juga mengenai fungsi Dinas Sosial yang sebenarnya. Menurutnya, sosialisasi terhadap kaum miskin sangat kurang padahal Dinas Sosial justru ditujukan untuk mereka.

Subyek mengalami kesulitan sekali ketika anaknya jatuh sakit karena tidak memiliki cukup uang untuk berobat. Subyek mengetahui dari teman-temannya bahwa jika hidupnya diatur oleh Dinas
Sosial, kesehatan belum tentu ditangani. Subyek merasa gelisah dengan keadaan seperti itu lantaran takut anaknya malah tidak terurus. Subyek cenderung mementingkan anaknya dibanding kesejahteraannya sendiri. Subyek merasa "begitu-gitu aja” dalam hidupnya namun ia bahagia lantaran anaknya sering terhibur apabila ada kegiatan seperti berjalan-jalan di taman, RPTRA, dan Monumen Nasional. Subyek membahas kehidupannya semakin membaik karena adanya taman-taman baru yang diciptakan pemerintahan sekarang. Kebahagiaan subyek lebih mencerminkan bagaimana kehidupan anaknya dan bukan berdasarkan materi hasil subyek memulung.

\section{PEMBAHASAN}

Peneliti melakukan analisis mengenai gambaran well-being dengan menggunakan aspek-aspek yang menyusun psychological well-being menurut Ryff (2008), yaitu sebagai berikut.

\section{Subyek 1}

\section{Kesejahteraan Sosial}

\section{Penerimaan diri (Self acceptance).}

Subyek 1 saat ini sudah menerima keadaan dirinya dengan ikhlas. Ia dapat bersyukur 
dengan pekerjaannya, walaupun hasil yang didapatkan tidak banyak. Walaupun penghasilannya terbatas, subyek sudah merasa bahagia jika dibandingkan saat dirinya di kampung halamannya.

\section{Hubungan positif dengan orang lain} (Positive relations with others). Subyek 1 dan subyek 2 tinggal bersama-sama dengan para geladangan, pengamen, pengemis, serta pemulung lainnya di salah satu kolong jembatan daerah Jakarta Barat. Menurutnya hubungan dirinya dengan teman-temannya cukup dekat, ia merasa bahagia saat mendapatkan banyak bantuan saat dirinya menderita sakit, kekurangan makanan, dan lainnya.

Kemandirian (Autonomy). Subyek memiliki kemandirian yang tinggi, subyek tinggal seorang diri di tengah kota Jakarta dan mengurus hidupnya sendiri seharihari. Ia bekerja memulung barang-barang bekas dan plastik tanpa memperdulikan masyarakat sekitar yang melihat dirinya. Tetapi berbagai macam tekanan sosial yang dirasakan subyek membuat subyek harus menyesuaikan dengan keadaannya, karena keadaan subyek di sini berbeda dengan saat di kampung halaman.

Tujuan hidup (Purpose in life). Subyek memiliki tujuan hidup tetapi sulit untuk mencapai tujuan tersebut karena kurangnya usaha dan tidak memiliki keyakinan dalam mencapai tujuan hidup tersebut. Subyek memiliki keinginan untuk tinggal di kampung halamannya dengan membuka warung, tetapi dengan keadaannya saat ini di kota sulit untuk mewujudkan keinginannya tersebut. Subyek pun hanya dapat berangan-angan dan tidak memiliki usaha dan kesempatan lebih untuk hal tersebut.

\section{Pengembangan pribadi (Personal} growth). Subyek tidak memiliki pengembangan pribadi yang baik karena keterbatasannya sehari-hari. Baginya, sekedar untuk memenuhi kebutuhannya saja sulit apalagi untuk mengembangkan potensi yang ada dalam dirinya. Subyek merasa tidak mampu mengembangkan atau sekedar memperbaiki kemampuan yang ia miliki saat ini.

Faktor-faktor lain yang mempengaruhi psychological well-being antara lain usia, tingkat pendidikan, jenis kelamin, status sosial ekonomi, dukungan sosial, kepribadian, dan spiritualitas (Papalia, 2002). Usia subyek 1 yang cukup tua yaitu 74 tahun membuat subyek dapat menerima keadaannya yang memiliki profesi sebagai pemulung, walaupun pada aspek pertumbuhan dan perkembangan pribadi subyek sudah mengalami penurunan yang 
cukup signifikan ditambah dengan penyakit stroke yang dideritanya. Tingkat pendidikan subyek yang rendah pun membuat subyek tidak memiliki pilihan pekerjaan lain yang lebih memadai. Status sosial ekonomi yang rendah di pedesaan membuat subyek memutuskan untuk merantau ke Jakarta untuk mengubah nasib, tetapi ternyata di Jakarta pun subyek tidak selalu dapat memenuhi kebutuhannya sehari-hari.

\section{Subyek 2}

Penerimaan diri (Self acceptance). Pada subyek 2 cukup berbeda, subyek tidak menerima keadaan dirinya yang sekarang, ia merasa anaknya perlu mendapatkan yang terbaik dan bersekolah bukan malah membantu dirinya mengumpulkan barang bekas. Walaupun begitu, tidak ada yang dapat dilakukannya selain bekerja sekeras mungkin setiap harinya. subyek merasa lebih mererima keadaan dilihat dari jawabannya yang menolak untuk pulang ke kampung halamannya.

\section{Hubungan positif dengan orang lain} (Positive relations with others). Banyak orang yang melihat subyek 2 sebagai ibu yang tega mempekerjakan anaknya, tetapi sebenarnya subyek 2 sendiri tidak memiliki pilihan yang lain karena anaknya sudah putus sekolah dan tidak dapat ditinggal sendirian. Subyek 2 tidak memperdulikan relasinya dengan orang lain dan cenderung cuek untuk menanggapi. Subyek senang apabila dirinya diterima apa adanya tanpa harus berpura-pura. Subyek menjelaskan rasa cuek ini timbul saat sudah memasuki tahun ketiga tinggal di Jakarta dan lebih mengutamakan hubungannya dengan sang anak.

Kemandirian (Autonomy). Subyek tersebut termasuk individu yang mandiri yang mampu mempertahankan hidupnya dengan hanya bekerja mengumpulkan barang bekas. Ia mungkin tidak dapat menerima keadaan yang sekarang ia jalani, akan tetapi ia tetap berusaha untuk mempertahankan hidup dengan mencari barang-barang bekas. Subyek yang merupakan seorang perempuan dengan anaknya mampu menghidupi dirinya dan anaknya tanpa sosok suami yang memberi nafkah.

Tujuan hidup (Purpose in life). Subyek memiliki beberapa tujuan dalam hidupnya, khususnya subyek berharap banyak terhadap anaknya sukses nantinya. Subyek ingin anaknya mendapatkan yang terbaik dan dapat bersekolah kembali, dan mendapat pekerjaan yang lebih baik dari 
saat ini. Subyek pun berharap pada pemerintah agar dapat memberikan tunjangan yang dapat membantunya dikemudian hari khususnya untuk anaknya yang masih memerlukan kepedulian dalam aspek pendidikan.

\section{Pengembangan pribadi (Personal} growth). Subyek pun sebenarnya ingin memiliki keterampilan lain yang dapat ia gunakan untuk mencari kerja sampingan selain memulung. Subyek ingin mengembangkan dirinya dengan keterampilan seperti memasak, menjahit, dan berbagai macam pekerjaan rumah lainnya yang membuat ia dapat bekerja menjadi Asisten Rumah Tangga (ART) yang berkompeten.

\section{SIMPULAN}

Dari berbagai aspek dalam wellbeing tersebut, peneliti dapat menyimpulkan adanya penghayatan dari hidup bahagia dari subyek 1 dan 2 sangat sederhana. Hanya dengan menjual banyak barang bekas dan dapat memenuhi kebutuhan mereka sehari-hari sudah menjadi kebahagiaan tersendiri bagi subyek, seperti subyek 2 yang akan senang jika kebutuhan anaknya hari itu terpenuhi walaupun dirinya tidak. Subyek merasa bahwa hidupnya saat ini memiliki tingkat kesejahteraan yang rendah, tetapi subyek berusaha menerima dirinya dan berusaha sebaik mungkin untuk bertahan hidup karena tidak dapat berbuat apa-apa untuk mengubahnya. Subyek juga merasa bahagia jika mendapatkan teman-teman seperjuangan di kolong jembatan, dan tidak memperdulikan masyarakat sekitar saat melihat subyek mencari barang bekas. Penghayatan subyek mengenai hidup bahagia tentunya juga diiringi dengan keinginan-keinginan terdalam subyek dalam kehidupannya, seperti membuka usaha, tinggal bersama keluarganya dan juga dapat sembuh dari penyakit strokenya tersebut. Dan subyek 2 ingin agar anaknya menjadi sukses, dan daat melanjutkan sekolahnya. Keduanya memiliki definisi bahagia dan sejahtera yang sederhana. subyek mengatakan bahwa dengan mengumpulkan barang yang banyak untuk dijual, dan dapat melihat anak (subyek 2) tersenyum sudah merupakan kebahagiaan dan mereka mengatakan bahwa mereka sejahtera dengan versi definisi yang sederhana.

Walaupun tingkat kesejahteraan kedua subyek rendah, tetapi kedua subyek masih dapat merasakan kebahagiaan dalam hidupnya dengan hal-hal yang sederhana sebagaimana yang terjadi dalam kehidupan 
mereka sehari-hari. Akhirnya kunci dari penghayatan hidup bahagia adalah mensyukuri hal yang telah diterima.

\section{SARAN}

Bagi pemerintah disarankan untuk dapat menyediakan lapangan pekerjaan, agar masyarakat yang memiliki tingkat kesejahteraan yang rendah dapat berjuang untuk memenuhi kebutuhan mereka. Apabila pemerintah tidak dapat membuka lapangan pekerjaan, setidaknya pemerintah dapat membuat atau membuka pelatihanpelatihan untuk melatih keterampilan masyarakat yang memiliki tingkat kesejahteraan yang rendah dan hasil dari kerajinan tangan mereka tersebut, dapat mereka olah untuk usaha yang akan mereka buat nantinya.

Bagi Masyarakat dapat membantu pemerintah dalam menjalankan programprogram yang ada untuk masyarakat yang memiliki tingkat kesejahteraan yang rendah. Masyarakat juga dapat berpartisipasi dalam membantu kegiatan pelatihan bagi PMKS dan kegiatankegiatan lainnya, contohnya bakti sosial. kegiatan amal dengan membagikan makanan atau uang santunan kepada para PMKS khususnya dijalan.

\section{DAFTAR PUSTAKA}

Adi, Isbandi R. 2004. Ilmu Kesejahteraan Sosial dan Pekerjaan Sosial: Pengantar pada Pengertian dan Beberapa Pokok Bahasan. Fisip UI Press. Jakarta.

Alvian. (2010). Psychological well-being ditinjau dari tipe coping stress pada siswa program akselerasi SMA Negeri 3 Surakarta. Skripsi Universitas Sebelas Maret.

Creswell, J. W. (2014). Research Design: Qualitative, Quantitative, and Mixed Methods Approach. London: Sage publications.

Diener, Ed \& Ryan, Katherine. (2009). Subjective Well Being: a General Overview. South African Journal of Psychology. Vol 39 (4), pp 391-406

Diener, Ed et al. (1999). Subjective Well Being: Three Decades of Progress. Psychological Bulletin. Vol 125 No 2. 276-302.

Dinas Sosial Pemerintah Provinsi DKI Jakarta. (2017). Statistik PMKS DKI Jakarta. Dinsos Jakarta. Diunduh pada https://dinsos.jakar

ta.go.id/page.php?cmd=data\&action $=p$ $\underline{\mathrm{mks}}$

Kartikasari, N,Y. (2013). Body dissatisfaction terhadap psychological well being pada karyawati. Skripsi, Universitas Muhammadiyah Malang.

Kementrian Sosial Republik Indonesia. (2012). Peraturan Pemerintah Nomor 39 Tahun 2012, tentang Penyelenggaraan Kesejahteraan Sosial. Kemendagri: Jakarta.

Kementrian Sosial Republik Indonesia. (2008). Data penyandang masalah kesejahteraan sosial. Jakarta.

Patnani, M. (2012). Kebahagiaan pada perempuan. Fakultas Psikologi Universitas YARSI. Jurnal Psikogenesis. Vol 1 (1). 
Republik Indonesia. (2009). UndangUndang RI Nomor 11 Tahun 2009 tentang Kesejahteraan Sosial.

Ryff, D.C. (1989). Happiness is everything, or is it? Exploration on the meaning of psychological well being. Journal of Personality and Social Psychology, 57, 1069-1081.

Ryan, M.R, \& Deci, L.E. (2001). On happiness and human potentials: a review of research on hedonic and eudaimonic well-being. Annu. Rev. Psychol, 52, 66-141.

Ryff, C.D., \& Singer, H.B. (2008). Know thyself and become what you are a eudiamonic approach to psychological well being. Journal of Happiness Studies, 9, 13-39.

Santrock, W, J. 2002. Life-span development perkembangan masa hidup (edisi kelima). Jakarta.

Schimmel, J. (2009). Development as Happiness: The Subjective Perception of Happiness and UNDP's Analysis of Poverty, Wealth and Development. Journal of Happiness Studies Vol 10 Issue 1, p93-111, 19p.

Snyder, R,C. \& Lopez, J.S. (2002). Handbook of positive psychology. Oxford University Press.

Sucianingsih. (2012). Dampak pelatihan dasar pekerjaan sosial terhadap kesejahteraan sosial masyarakat. Skripsi Fakultas Pendidikan Universitas Pendidikan Indonesia: Bandung.

Thamrin, H., Masril, M., \& Sembiring W. M. (2016). Model of Social Service In Empowerment of Social Welfare Issue In Medan. Medan: Universitas Sumatera Utara.
Williams, K, Brian; Sawyer, C, Stacey \& Wahlstrom, M, Carl. (2006). Marriages, Families \& Intimate Relationship. A Practical Introduction. USA: Pearson Education, Inc. Diunduh pada

http://www.wikimu.com/News/Display News.aspx?id=5530 